\title{
A Review of Metabolic Disorder of Amino Acid Tyrosinemia type I: When to Suspect and how to Diagnose
}

\author{
Hanna Alobaidy ${ }^{1.2}$ \\ ${ }^{1}$ Pediatrics Department Metabolic Clinic, Elkhadra hospital Tripoli Libya \\ ${ }^{2}$ Pediatrics department Tripoli University, Faculty of Medicine Tripoli Libya
}

\begin{abstract}
Background: Hereditary Tyrosinemia I (HT1) is an inborn error of tyrosine catabolism; an autosomal recessive disorder caused by defective activity of fumarylacetoacetate hydrolase (FAH) enzyme, is characterized by progressive liver disease, renal tubular dysfunction, and porphyria-like crises. Succinylacetone (SA); a compound derived from the tyrosine catabolic intermediate fumarylacetoacetate has been demonstrated to be a mitochondrial toxin. Symptoms may start during the first few months (acute type); in second half of the first year (subacute type) or in the following years up to adulthood (chronic type). All patients stand a high risk of developing hepatocellular carcinoma (HCC) secondary to cirrhosis. Diagnostic methods: Elevated levels of SA, a fetoprotein and plasma levels of tyrosine, phenylalanine and methionine, Newborn screening and prenatal diagnosis are available in many countries. Management and treatment: A dramatic improvement in prognosis following treatment with Nitisinone, along with protein-restricted diet and option of liver transplantation in acutely ill infants fails to respond to Nitisinone, or diagnosed HCC. Conclusion: HTI is a treatable disease, it has heterogeneous hepatorenal manifestations. Elevated levels of SA in plasma or urine are diagnostic. An early diagnosis and treatment with Nitisinone is critical to normal development and survival. Individuals should follow a life-long low-tyrosine and phenylalanine diet.
\end{abstract}

Keywords: Hepatorenal tyrosinemia, Succinylacetone, Nitisinone, Hepatocellular carcinoma (HCC).

\section{Introduction}

When the specific enzymatic diagnosis was unavailable, the term tyrosinemia was given to a clinical presentation with elevated blood tyrosine levels that including transient tyrosinemia of the newborn (TTN), hereditary infantile tyrosinemia (tyrosinemia type I), Richner-Hanhart syndrome (tyrosinemia type II) and tyrosinemia type III. Transient tyrosinemia is benign condition due to delayed enzyme maturity in the Tyrosine pathway and resolved spontaneously, TTN is not categorized as an inborn error of metabolism because it is not caused by a genetic mutation. Tyrosinemia type II is a disease caused by tyrosine aminotransferase deficiency with a clinical presentation includes mental retardation, herpetiform corneal ulcers, and skin hyperkeratotic lesions of the digits, palms, and soles [1,2]. Tyrosinemia type III is an extremely rare disorder caused by deficiency of 4-hydroxyphenylpyruvate dioxygenase, with clinical presentation of intermittent ataxia, without hepatorenal involvement or corneal ulcers or skin lesions [3].

Hereditary Tyrosinemia type 1 (HTI) is an amino acid disorder, which was the first described in 1950 [4]. In the late 1970s, the biochemical and enzymatic defect in the enzyme fumarylacetoacetate hydrolase (FAH) results in accumulation of fumaryl- and maleyl-acetoacetate that cause hepatorenal damage were reported, and described a succinylacetone (SA) found in the urine; a compound derived from the tyrosine catabolic intermediate fumarylacetoacetate, SA has been demonstrated to be a mitochondrial toxin [1]. The accumulation of SA and succinylacetoacetate (SAA) lead to accumulation of delta-aminolevulinate ( $\delta$-ALA) resulting in inhibition of porphobilinogen synthesis and porphyria-like crises (Fig.1). HTI also known as hepatorenal tyrosinemia is an autosomal recessive disorder with a worldwide birth incidence of approximately 1 in 100,000 with the highest prevalence in the French, Canadian and Scandinavian population [5, 6, 7]. Different mutations in FAH gene have been identified in different races around the world [7, 8, 9].

HT1 is clinically heterogenous (Table 1), symptoms may start during the first few months (acute type), in second half of the first year (subacute type) or in the following years up to adulthood (chronic type) [10]. If the child is not treated, it will develop liver failure and/or hepatocellular carcinoma $[1,10,11,12]$. The most sensitive diagnostic test is for succinylacetone that maybe measured in plasma, urine or dried blood spots as used in newborn screening (NBS) [11, 13]. Treatment with Nitisinone (NTBC) (2-(2-nitro-4fluoromethylbenzoyl)-1,3-cyclohexanedione)) can prevent liver, kidney, and neurological symptoms if started immediately [11, 12, 13, 14, 15, 16,17]. Patients should follow a life-long low-tyrosine and phenylalanine diet, which generally requires both medical formulas and foods $[11,15,18,19]$.

The aim of this article is to increase disease awareness of the timing of diagnosis by focusing on clinical presentation where general pediatrician and family doctors may initiate evaluation of suspected patients, and then they should be referred to specialist center in order to start disease-specific treatment. 


\section{Clinical Signs and Organs manifestation in Tyrosinemia type I (HTI) (Table 2)}

It is challenging to diagnose patients with HTI; they can present to different health care professionals. Children with tyrosinemia type 1 can display variable symptoms; the acute form usually appears in the first few months of life, while Children with the chronic form develop symptoms gradually although the typical features may not all be present, infants presenting before age six months usually have acute liver failure with dysfunction of clotting factors $[10,11,18,19,20]$. Neurologic crises, a porphyria-like syndrome usually precipitated by intercurrent infection, lasting one to seven days that can include change in mental status, seizures, painful parasthesias (causing patients to assume ophisthotonic position and self mutilation), autonomic signs (hypertension, tachycardia, ileus), abdominal pain, peripheral neuropathy, and/or respiratory failure requiring mechanical ventilation. Recently, psychomotor impairment has been observed in a number of patients [11, 21, 22]. Children may have a characteristic odor of cabbage like or rotten mushrooms [22]. HTI patients at risk to develop cirrhosis, liver nodules, and hepatocellular carcinoma (HCC), they may present with any of these on clinical examination the liver is firm or even hard $(10,11,22)$.

\section{Diagnostic methods}

3.1. Newborn screening (NBS), either Tyrosinemia type I, is detected on newborn screening or classically presents as severe liver disease in young infants or in children older than age six months may come to medical attention with signs of renal disease, Vitamin D resistant rickets. Babies with HTI are rarely symptomatic in the first days of life.

Newborn screening is available in some countries; liver damage is prenatal in onset (as indicated by greatly elevated alpha-fetoprotein in cord blood) and that hypertyrosinemia developed only postnatally. In newborn screening laboratories, Succinylacetone is now a routine biomarker for tyrosinemia type I, because it is most sensitive and specific test can be identified shortly after birth in asymptomatic newborn, may be measured in plasma, dried blood spot, or urine. Blood spot tyrosine is neither specific nor sensitive [23, 24].

3.2. Diagnostic tests (Table 3): Initial tests may show typical biochemical findings include: Liver function tests are usually severely affected with markedly prolonged Prothrombine time (PT) and partial thromboplastin time (PTT), factor II, VII, IX, XI, and XII levels are decreased and factor V and factor VIII levels are preserved, hypoalbuminemia, high alkaline phosphatase (ALP), modestly high level of transaminase (AST and ALT) and gamma glutamyl transpeptidase (GGT), serum bilirubin concentration may be normal or only slightly elevated. The renal tubular dysfunction involves features of Fanconi syndrome with generalized aminoaciduria, phosphate loss and glucosuria, hypophosphatemia, serum calcium concentration is usually normal. X-ray of wrist document possible presence of rickets resulting from renal tubular damage. Markedly elevated serum concentration of alpha-fetoprotein (average 160,000 ng/ml) (normal: $<1000 \mathrm{ng} / \mathrm{mL}$ for infants age 1-3 months and $<12 \mathrm{ng} / \mathrm{mL}$ for children age 3 months to 18 years) [22, 25] but it is not specific, it is indicator of liver damage, however newborn babies diagnosed by screening have markedly raised AFP levels [26, 27]. Elevated levels of SA in dried blood spots, plasma, or urine are pathognomonic, a routine organic acid assays may not be sufficiently sensitive to detect SA if it is very low or the urine very dilute, a specific assay is needed. Other abnormal results are increased plasma levels of tyrosine, phenylalanine and methionine (that are present with any severe liver disease), increased urinary $\delta$-ALA excretion in neurological crisis. Imaging: an abdominal ultrasound examination and CT Scan evaluation (cases with suspicion of hepatocarcinoma) of the liver and kidneys at presentation should be done for echogenicity of hepatic parenchyma and nodular lesions and kidneys size with possible of nephromegaly.

\section{Management and treatment (Table 4)}

There are three strategies for treatment of tyrosinemia type 1, Medication, Dietary treatment and Liver transplantation.

\subsection{Medication:}

Treatment of manifestations: With Nitisinone, the brand name is Orfadin, it was previously known as NTBC [2-(2 nitro- 4- 3trifluoro-methybenzoyl)-1, 3-cyclo hexanrdione]. Since 1992, the treatment of tyrosinemia type 1 has changed completely and has transformed the prognosis of the disease when Lindstedt et al. reported their first results with NTBC [28]. Nitisinone was approved by the Food and Drug Administration (FDA) in 2002 for the treatment of HTI; it is available in $2 \mathrm{mg}, 5 \mathrm{mg}, 10 \mathrm{mg}$ and $20 \mathrm{mg}$ capsules. Nitisinone is a medication that blocks the formation of fumarylacetoacetate and succinylacetone and prevents accumulation of toxic and carcinogenic metabolites (Fig.1).

The dose of Nitisinone: In a usual dose of Nitisinone $1 \mathrm{mg} / \mathrm{kg} / \mathrm{d}$ in $2-3$ doses per day, or recently once a day dose, as the half life is $54 \mathrm{hrs}$, to the dose of $2 \mathrm{mg} / \mathrm{kg} / \mathrm{d}$ should be given to all patient with acute severe liver failure from the start, along with the emergency treatment for acute liver failure, and allow the dose to fall with 
growth to $1 \mathrm{mg} / \mathrm{kg} / \mathrm{d}$ before increasing it; that can prevent liver failure, renal tubular dysfunction and porphyria like crisis but cannot prevent the potential risk of developing of Hepatocelullar Carcinoma (HCC). All patients must be followed carefully, monitored, and adjusted regularly based on plasma phenylalanine and tyrosine levels, plasma nitisinone concentrations (dosage should be adjusted to maintain blood Nitisinone levels between 40 and $60 \mu \mathrm{mol} / \mathrm{L}$ ), growth and weight gain [11, 14, 29]. Nitisinone is safe and well-tolerated medicine with few side effects, which resolved with stricter dietary control (Table 5) [30]. Treatment of secondary complications: Of early signs of carnitine, deficiency and rickets that are secondary to renal tubular Fanconi syndrome are treated by correction of acidosis, restoring calcium, and phosphate balance, and administration of 25-hydroxy-vitamin D.

4.2. Diet: Nitisinone is a potent inhibitor of 4-hydroxyphenylpyruvate dioxygenase, interferes with the production of succinylacetate by stopping the conversion of $\mathrm{p}-\mathrm{OH}-\mathrm{phenylpyruvic}$ acid to homogentisic acid, and as a result is markedly decrease in the concentrations of succinylacetone and an increase in the concentrations of tyrosine levels. In order to prevent high tyrosine levels, dietary intake of low tyrosine low phenylalanine diet is necessary. With appropriate dietary management, Physicians and nutritionists work with each family to develop a formula and food pattern that maintains plasma tyrosine levels below $500 \mu \mathrm{mol} / \mathrm{l}$, plasma phenylalanine concentration should be $20-80 \mu \mathrm{mol} / \mathrm{l}(0.3-1.3 \mathrm{mg} / \mathrm{dl})$; by using a vegetarian diet with low-protein foods and a medical formula, the amount of phenylalanine and tyrosine needs changes with growth and during times of illness $[11,15,22,30]$. As many patients on Nitisinone have learning difficulties [31, 32], eye complications, and it is thought that this is associated with the increased tyrosine concentrations [33, 34].

4.3. Liver transplantation: Prior to the availability of Nitisinone, the only available therapy was a liver transplantation. The indications for liver transplantation include; children who have severe liver failure at clinical presentation, children fail to respond to nitisinone therapy, children have evidence of HCC with changes in hepatic tissue or suspected because of radiological or serological investigations or treatment with Nitisinone is not available $[11,35]$, the patient should be evaluated by a liver transplantation team. Transplant recipients require lifelong immune suppression to prevent rejection of the new liver for the rest of their lives, and to lowdose $(0.1 \mathrm{mg} / \mathrm{kg} / \mathrm{day})$ Nitisinone therapy to prevent continued renal tubular and glomerular dysfunction resulting from persistence of succinylacetone in the plasma and urine, mortality associated with liver transplantation in young children is $10 \%$ or higher $[11,36,37]$.

\section{Disease Monitoring (Table 6)}

With combination of medication and diet by use of Nitisinone to prevent the formation of succinylacetone and the use of a diet low in tyrosine and phenylalanine to minimize the amount of tyrosine that needs to be metabolized, most patients grow at appropriate rates, have improved liver function and avoid kidney problems, liver cirrhosis and hepatic malignant change.

The patients should be frequently monitored and carefully supervised; the frequency should take account of the age of the patient and the severity of the illness at presentation. Chick adequacy of treatment by frequent measurement shown in suggested guidelines for monitoring in HTI in (Table 6) [11, 22, 38]. The patient should be seen every month (or even every week) until the patient is stable and well controlled. Monitoring of alpha-fetoprotein and urine succinylacetone, CBC and chemistries should do monthly during the first 6 months of treatment. If the patient is in acute liver failure plasma glucose and ammonia should be added. Abdominal CTs are performed annually, hepatic imaging must also be done without delay if there is any rise or failure of the expected fall in AFP, or if there is development of a new nodule or a nodule is larger than $10 \mathrm{~mm}$ in diameter, HCC is likely and the patient should be referred to be discussed with a liver transplantation team. Liver biopsy should be avoided because of the risk of metastases [11, 12, 22, 25, 39].

5.1. Psychometric assessment and monitoring: The first assessment of intellectual development should be before school entry and at intervals thereafter, school reports may be more helpful to supplement the assessment. Recent data indicate that HT1 patients with elevated plasma tyrosine concentrations under Nitisinone treatment have neurocognitive problems, by using standardized psychometric test batteries, these patients performed subnormal in the assessment of development, motor function, and speech. Further data reveal patients showed poorer estimated IQ, executive functioning working memory and cognitive flexibility, and social cognition compared to healthy controls, and that IQ screening were estimated is not sufficient for cognitive monitoring of these patients. Further researches are needed focusing on the underlying pathphysiological mechanisms of these impairments [11, 32, 40].

5.2. Ophthalmic examination: Annual eye examination with a slit lamp may be indicated. Nitisinone blocks the tyrosine catabolic pathway such that increases the blood concentration of tyrosine, blood tyrosine concentration greater than $600 \mathrm{~mol} / \mathrm{l}$ confers risk of precipitation of tyrosine crystals in the cornea as bilateral, linear, branching subepithelial corneal opacities causing photophobia and itchy, sensitive eyes. The crystals 
resolve once tyrosine levels are reduced by dietary management with controlled intake of phenylalanine and tyrosine $[33,34,41]$.

5.3. Signs of response and poor response to Nitisinone are: Usually rapid improve of coagulation defect within 48 hours up to one week. Undetectable Succinylacetone in the urine and blood after the first 24 hours. Increase of plasma tyrosine level because of the inhibition of the 4-hydroxyphenyl pyruvate dioxygenase. Marked improvement in the liver function within one week. AFP can take up to one year or even longer to fall to normal value. Signs of poor response to Nitisinone: Unrecovered from severe liver failure, liver function does not normalize. Succinylacetone can still be detected in plasma and/or urine[11,13].Failure to normalize of AFP or a secondary rise should be regarded with suspicion, imaging should be done without delay $[25,27,39,42]$.

5.4. Long-term HTI complication: Liver cirrhosis, liver failure, hepatocellular carcinoma and porphyria-like syndrome were frequent before Nitisinone used as treatment, while hepatocellular carcinoma is still important risks of long term complications even in patients when being treated with Nitisinone.

\section{Differential diagnosis (Table 7) $[22,43,44]$}

Because newborn screening for HTI is only available in some countries, the diagnosis is not easy. Most patients presented clinically which can be variable. HT1 is a multi-organ disease; most important effected organs are liver, kidneys, and central nervous system.

\section{Prognosis}

Unrecognized and untreated infants diagnosed before age two months had a two-year survival rate of $29 \%$, most infants die from liver failure within weeks or months of first symptoms [10, 22]. Among untreated chronic form those diagnosed after age six months had a $96 \%$ two-year survival rate, of who do not die from their symptoms in early infancy, they may die from liver cirrhosis or liver tumors, usually before 10 years of age. HCC has not been reported in individuals who were with Nitisinone therapy prior to age 30 days, while a delay results in an increased risk up to 12 folds in children who were placed on older than one year. Affected children younger than age two years who are treated with a combination of Nitisinone and low-tyrosine diet has resulted in a greater than $90 \%$ survival rate, improved liver function, prevention of liver cirrhosis, correction of renal tubular acidosis, and improvement in hypophosphatemic rickets $[10,15,22,45]$.

\section{Molecular genetic testing and family screening}

Tyrosinemia type 1 is inherited an in autosomal recessive manner, mutations in the FAH gene cause tyrosinemia type I, each parent to effected child carry one copy of mutated gene, each pregnancy between carrier parents has a $25 \%$ risk of producing a child affected with HTI, a $25 \%$ chance of producing a child who is unaffected and is not a carrier and $50 \%$ chance of producing an unaffected carrier child.

FAH gene is located on chromosome $15 \mathrm{q} 23$-q25, is approximately $35 \mathrm{kbp}$ in size and comprises 14 exons, the 95 mutations in FAH gene have been identified in different races around the world and are now known. The most frequent mutation encountered is the IVS $12+5 \mathrm{G}>\mathrm{A}$ splice mutation, which accounts for $33.7 \%$ of all HT1 alleles, followed by the IVS6-1G>T mutation $(16.4 \%)[5,6,46,47]$ (Table 8). The identification of these mutations in groups at high risk is not essential for clinical management but is useful for prenatal diagnosis and reproductive counseling and in carrier detection. No correlation is observed between clinical presentation and genotype. Two regions of the world have a higher than expected frequency of tyrosinemia type I, in Norway and Finland, French settlers in the province of Quebec, Canada; most likely due to fact that all newborns are screened there for HT1 [7, 22, 46, 47].

8.1. Antenatal diagnosis: Can be used to clarify the status of at-risk sibs before birth, to enable the earliest possible diagnosis and treatment after birth. Prenatal testing can be done by either 1- Mutation analysis on chorionic villus sampling (CVS), if the familial causative mutations are known or 2- By fumarylacetoacetate hydrolase (FAH) enzyme assay on CVS or 3- SA levels in amniotic fluid obtained by amniocentesis usually performed at approximately 15 to 18 weeks' gestation. A subsequent child of the parents of a child with HTI who has not had a prenatal diagnosis should send a cord blood_or urine (collected at around 6-12 hours of age) for analysis of succinylacetone [48].

8.2. Preimplantation genetic diagnosis (PGD): may be an option if the $F A H$ pathogenic variants have been identified in an affected family member.

8.3. Genetic counseling: Discussion of potential risks to offspring to young adults who are known as a carrier or to parents of a previously affected child, the risk of child being affected is a $1 \mathrm{in} 4$. Genetic counseling is the process of providing individuals medical information to help them make a personal decision of termination of the pregnancy with affected fetus, the ethical issues, and the laws are vary widely in countries.

8.4 Nitisinone during pregnancy: At least two patients have given birth to clinically healthy infants while receiving Nitisinone. In recent clinical experience, it is believed that the pregnant affected mother remains safe, while the fetus may be at risk because of alterations of maternal tyrosine metabolism. In the first affected mother 
who gave birth to an unaffected infant. In another pregnancy, an affected woman gave birth to an affected child who was clinically normal on examination, there no detectable succinylacetone in the bloodspot of the newborn screening and normal plasma alpha-fetoprotein concentrations, it suggested that the Nitisinone crossed the placenta and suppressed the disease; the diagnosis of HTI was confirmed by molecular study [22, 49, 50]. Longterm follow up studies in a larger cohort of pregnancies and births are needed.

New Nitisinone form therapy: Nitisinone is available in oral suspension since April 2016, as a $4 \mathrm{mg} / \mathrm{ml}$ liquid, is specially developed for small infants and toddlers, strawberry-flavored using a dosing oral syringe without dilution [51] no data exist on the use of nitisinone suspension in affected individuals.

New Ongoing Biomarkers Based on Experimental Data: For the diagnosis of hepatocellular carcinoma (HCC) in HTI, a parameter for early detection of tumor would help in the follow-up. By using a HT1 murine model, have been reported the changes in profiles of circulating and hepatic microRNAs (miRNAs) during the liver neoplastic process, the significant changes in miRNAs levels are detectable prior to an increase in the current biomarker for HCC diagnosis AFP [52].

\section{Conclusion}

Tyrosinemia type I HTI is a genetic disorder with onset varies from infancy to adolescence. Patients often present with wide clinical spectrum ranging from chronic complication of liver failure to renal tubular dysfunction and hypophosphatemic rickets, to hepatocellular carcinoma making for difficult and often delayed diagnosis. The diagnosis is confirmed through urine or plasma analysis of succinylacetone. Early diagnosis and treatment with Nitisinone in combination with dietary restrictions is the key to successful treatment. Newborn screening is essential for the early diagnosis. There is a need for raising disease awareness and improving early detection, for optimal disease management. Mutation analysis is useful for prenatal diagnosis and family planning.

\section{References}

[1]. Karl S Roth, Mary L Windle, Luis O Rohena, Erawati V Bawle. Tyrosinemia (Internet).Medscape(Internet). Aug.13, 2015.

[2]. Iskeleli G, Bilgeç MD, Arici C, Atalay E, Ogreden T, Aydin A. Richner-Hanhart syndrome (tyrosinemia type II): a case report of delayed diagnosis with pseudodendritic corneal lesion. Turk J Pediatr, 53(6) 2011:692-4.

[3]. R Cerone, E Holme, MC Schiaffino, U Caruso, L Maritano and C Romano. Tyrosinemia type III: diagnosis and ten-year follow-up. Acta Paediatrica, Volume 86, Issue 9, 1997 : 1013-1015.

[4]. Himsworth HP Lectures on the liver and its diseases (2ndedn) (Oxford: Blackwell, 1950).

[5]. De Braekeller M, Larochelle J. Genetic epidemiology of hereditary tyrosinemia in Quebec and Saguenay-Lac-St-Jean, American Journal of Human Genetics, Vol. 47 1990: 302-307.

[6]. Linblad B, Lindstedt S, Steen G. On the enzyme defects in hereditary tyrosinemia, proceeding of the National Academy of Sciences of the United States of America 74 1997: 4641-4645.

[7]. Arranz JA, Pinol F, Kozak L, Petez-Cerda C, Cormand B, et al. Splicing mutations, mainly IVS6-1 (G>T), account for 70\% fumarylacetoacetate hydrolase (FAH) gene alterations, including 7 novel mutations, in a survey of 29 tyrosinemia type 1 patients. Hum Mutant.20 2002:180-188.

[8]. Vazifehmand R, Ali DS, Ahangarkolaee SAG, Poor MJR. Identification of a Rare Mutation Causing Hereditary Tyrosinemia Type 1 in an Iranian Child Compound with Dextrocardia Phenotype. Intern Med 6 2016: 210. doi:10.4172/2165-8048.1000210.

[9]. Phaneuf D, Labelle Y, Berube D, Arden K, Cavenee W, et al. Cloning and expression of the cDNA encoding human fumarylacetoacetate hydrolase, the enzyme deficient in hereditary tyrosinemia : Assigriment of the gene to chromosome 15 . AM $\mathrm{J}$ Hum Genet 48 1991:525-535.

[10]. van Spronsen FJ, Thomasse Y, Smit GP, Leonard JV, Clayton PT, Fidler V, Berger R, Heymans HS: Hereditary tyrosinemia type I: a new clinical classification with difference in prognosis on dietary treatment. Hepatology 20 1994: 1187-1191.

[11]. Corinne de Laet, Carlo Dionisi-Vici, James V Leonard, Patrick McKiernan, Grant Mitchell, Lidia Monti, Hélène Ogier de Baulny, Guillem Pintos-Morell and Ute Spiekerkötter. Recommendations for the management of tyrosinaemia type 1. Orphanet Journal of Rare Diseases 8 2013:8-8 DOI: 10.1186/1750-1172.

[12]. Schiff M, Broue P, Chabrol B, De Laet C, Habes D, Mention K, et al. Heterogeneity of follow-up procedures in French and Belgian patients with treated hereditary tyrosinemia type 1: results of a questionnaire and proposed guidelines. J Inherit Metab Dis. 35(5) 2012: 823-9.

[13]. Holme E, Lindstedt S: Tyrosinemia type I and NTBC. J Inher Metab Dis. 21 1998: 507-517.

[14]. Schlune A, Thimm E, Herebian D, Spiekerkoetter U: Single dose NTBC treatment of hereditary tyrosinaemia type 1. J Inherited Metab Dis. 35 2012: 831-836.

[15]. Masurel-Paulet A, Poggi-Bach J, Rolland MO, Bernard O, Guffon N, Dobbelaere D, et al. NTBC treatment in tyrosinaemia type I: long-term outcome in French patients. J Inherit Metab Dis. 31(1) 2008: 81-7.

[16]. El-Karaksy H, Rashed M, El-Sayed R, El-Raziky M, El-Koofy N, El-Hawary M, et al. Clinical practice. NTBC therapy for tyrosinemia type 1: how much is enough? Eur J Pediatr.169(6) 2010: 689-93.

[17]. Hall MG, Wilks MF, Provan WM, Eksborg S, Lumholtz B: Pharmacokinetics and pharmacodynamics of NTBC (2-(2-nitro-4fluoromethylbenzoyl)-1,3-cyclohexanedione) and mesotrione, inhibitors of 4-hydroxyphenyl pyruvate dioxygenase (HPPD) following a single dose to healthy male volunteers. Br J Clin Pharmacol. 52 2001: 169-177. 
[18]. Chakrapani A, Gissen P, McKiernan P, Disorders of Tyrosine Metabolism, in Saudubray J-M, Berghe G, Walter JH. Heidelberg (Ed.), Inborn Metabolic Diseases, 5 (Springer 5 2012) 275-276.

[19]. Croffie JM, Gupta SK, Chong SK, Fitzgerald JF. Tyrosinemia type 1 should be suspected in infants with severe coagulopathy even in the absence of other signs of liver failure, Pediatrics. 103 $1999: 675-8$.

[20]. Vogel A, van Den Berg IE, Al-Dhalimy M, Groopman J, Ou CN, Ryabinina O, Iordanov MS, Finegold M, Grompe M. Chronic liver disease in murine hereditary tyrosinemia type 1 induces resistance to cell death. Hepatology. 39 2004:433-43.

[21]. Mitchell G, Larochelle J, Lambert M, Michaud J, Grenier A, Ogier H, Gauthier M, Lacroix J, Vanasse M, Larbrisseau A, et al. Neurologic crises in hereditary tyrosinemia. N Engl J Med.322 1999 :432-7.

[22]. Sniderman King L, Trahms C, Scott CR. Tyrosinemia type I(Internet). Gene Reviews \{Internet\}. July 2014.

[23]. Schlump JU, Mayatepek E, Spiekerkoetter U: Significant increase of succinylacetone within the first $12 \mathrm{~h}$ of life in hereditary tyrosinemia type 1. Eur J Pediatr.169 2010 : 569-572.

[24]. Al-Dirbashi OY, Mohamed S, Rashed MS, Jacob M, Al-Ahaideb LY, Al-Amoudi M, Rahbeeni Z, Al-Sayed MM, Al-Hassnan Z, Al-Owain M, Al-Zeidan H. Improved method to determine succinylacetone in dried blood spots for diagnosis of tyrosinemia type 1 using UPLC-MS/MS. Biomed Chromatogr. 22 $2008: 1181-5$.

[25]. Koelink CJ, van Hasselt P, van der Ploeg A, van den Heuvel-Eibrink MM, Wijburg FA, Bijleveld CM, van Spronsen FJ: Tyrosinemia type I treated by NTBC: how does AFP predict liver cancer?. Mol Genet Metab. 89 2006 : 310-315.

[26]. Hostetter MK, Levy HL, Winter HS, Knight GJ, Haddow JE: Evidence for liver disease preceding amino acid abnormalities in hereditary tyrosinemia. N Engl J Med. 308 1983: 1265-1267.

[27]. Alobaidy H and Barkaoui E. Experience of a Single Center in NTBC Use in Management of Hereditary Tyrosinemia Type I in Libya. Iran Journal of Pediatrics, Vol. 25 Issue 5, Oct 2015.

[28]. Lindstedt S. Holme E, Lock EA et al.: Treatment of hereditary tyrosinemia type 1 by inhibition of 4 - hydroxyphenylpyruvate dioxygenase. Lancet $3401992: 813-817$.

[29]. Van Sponsen FJ. Smith GPA, Wijburg FA et al.Tyrosinemia type 1 consideration on treatment strategy and experiences with risk assessment, diet and transplantation. J Inher Metab Dis, 18 1995:111-114.

[30]. Nitisinone (Oral Route) side effects. Mayoclinic.com. [Internet] 2015-04-01.

[31]. De Laet C, Munoz VT, Jaeken J, François B, Carton D, Sokal EM, Dan B, Goyens PJ: Neuropsychological outcome of NTBCtreated patients with tyrosinaemia type 1. Dev Med Child Neurol. 532011 : 962-964.

[32]. Thimm E, Richter-Werkle R, Kamp G, Molke B, Herebian D, Klee D, Mayatepek E, Spiekerkoetter U: Neurocognitive outcome in patients with hypertyrosinemia type I after long-term treatment with NTBC. J Inherit Metab Dis. 35 2012 : 263-268.

[33]. Gissen P, Preece MA, Willshaw HA, McKiernan PJ: Ophthalmic follow-up of patients with tyrosinaemia type I on NTBC. J Inherit Metab Dis. $262003: 13-16$.

[34]. Lock EA, Gaskin P, Ellis M, Provan WM, Smith LL: Tyrosinemia produced by 2-(2-nitro-4-trifluoromethylbenzoyl)-cyclohexane1,3-dione (NTBC) in experimental animals and its relationship to corneal injury. Toxicol Appl Pharmacol. 215 2006: 9-16.

[35]. Bartlett DC, Lloyd C, McKiernan PJ, Newsome PN. Early nitisinone treatment reduces the need for liver transplantation in children with tyrosinaemia type 1 and improves post-transplant renal function. J Inherit Metab Dis. 37(5) 2014 :745-52.

[36]. Pierik LJ, van Spronsen FJ, Bijleveld CM, van Dael CM. Renal function in tyrosinaemia type I after liver transplantation: a longterm follow-up. J Inherit Metab Dis. 28 2005:871-6.

[37]. Baritlett DC, Preece MA, Holme E, Lloyd C, Newsome PN, Mckiernan PJ. Plasma succinylacetone is persistently raised after liver transplantation in Tyrosinemia Type I.J Inherit Metab Dis. 36 2013: 15-20.

[38]. Laboratory Monitoring of Tyrosinemia Type I with Nitisinone. University of Washington Biochemical Genetics Clinic, Seatile.WWW. Depts.Washington.edu/Tyros/Pdfs/Labs.PDF. Accessed May 2008.

[39]. Alobaidy H, Yahya N, Said R. Tyrosinemia type I. Clinical and biochemical analysis of cases with poor treatment outcome. Jordan Medical Journal. Vol.45 (2) 2011: 205-212 http:/ dar.ju.edu.jojmj.

[40]. Van Ginkel WG, Jahja R, Huijbregts SC, Daly A, MacDonald A, De Laet C, Cassiman D, Eyskens F, Körver-Keularts IM, Goyens PJ, McKiernan PJ, van Spronsen FJ. Neurocognitive outcome in tyrosinemia type 1 patients compared to healthy controls. Orphanet J Rare Dis. ;11(1) $2016: 87$.

[41]. Ahmad S, Teckman JH, Lueder GT. Corneal opacities associated with NTBC treatment. Am J Ophthalmol. 134(2) 2002 :266-8.

[42]. Mohan N, Mckiernan P, Preece MA, Green A, Buckels J, Mayer AD, Kelly DA. Indications and outcome of liver transplantation in Tyrosinemia Type I, Eur J Pediatr, 58 suppl 2 1999: S49-54.

[43]. Techakittiroj C, Cunningham A, Hooper PF, Andersson HC, Thoene J. High protein diet mimics hypertyrosinemia in newborn infants. J Pediatr, $1462005: 281-2$.

[44]. Hendriksz CJ, Walter JH. Feeding infants with undiluted goat's milk can mimic tyrosinaemia type 1. Acta Paediatr, $932004: 552-3$.

[45]. McKiernan PKJ. Nitisinone in the treatment of hereditary tyrosinaemia type 1. Drugs, $662006: 743-50$.

[46]. Online Mendelian Inheritance in man: Tyrosinemia type1. http://omim.org/entry/276700.

[47]. Angileri F, Bergeron A, Morrow G, Lettre F, Gray G, Hutchin T, Ball S, Tanguay RM. Geographical and Ethnic Distribution of Mutations of the Fumarylacetoacetate Hydrolase Gene in Hereditary Tyrosinemia Type 1. IMD Rep. 19 2015:43-58.

[48]. Larochelle J, Alvarez F, Bussières JF, Chevalier I, Dallaire L, Dubois J, Faucher F, Fenyves D, Goodyer P, Grenier A, Holme E, Laframboise R, Lambert M, Lindstedt S, Maranda B, Melançon S, Merouani A, Mitchell J, Parizeault G, Pelletier L, Phan V, Rinaldo P, Scott CR, Scriver C, Mitchell GA: Effect of nitisinone (NTBC) treatment on the clinical course of hepatorenal tyrosinemia in Québec. Mol Genet Metab.107 2012: 49-54.

[49]. Vanclooster A, Devlieger R, Meersseman W, Spraul A, Vande Kerckhove K, Vermeersch P, Meulemans A, Allegaert K, Cassiman D: Pregnancy during nitisinone treatment for tyrosinemia type I: first human experience. J Inherit Metab Dis. JIMD Rep, 52012 : 27-33.

[50]. Garcia Segarra N ${ }^{1}$, Roche S, Imbard A, Benoist JF, Grenèche MO, Davit-Spraul A, Ogier de Baulny H. Maternal and fetal tyrosinemia type I. J Inherit Metab Dis.; 33 Suppl 32010 :S507-10.

[51]. Online Tyrosinemia type I. NIH (internet) Tyrosinemia type I https://rarediseases.info.nih.gov/diseases/2658/tyrosinemia-type-1.

[52]. Angileri, F. et al. Identification of circulating microRNAs during the liver neoplastic process in a murine model of hereditary tyrosinemia type 1. Sci. Rep. $62016,27464$.

Table 1. The clinical presentation according to disease onset 


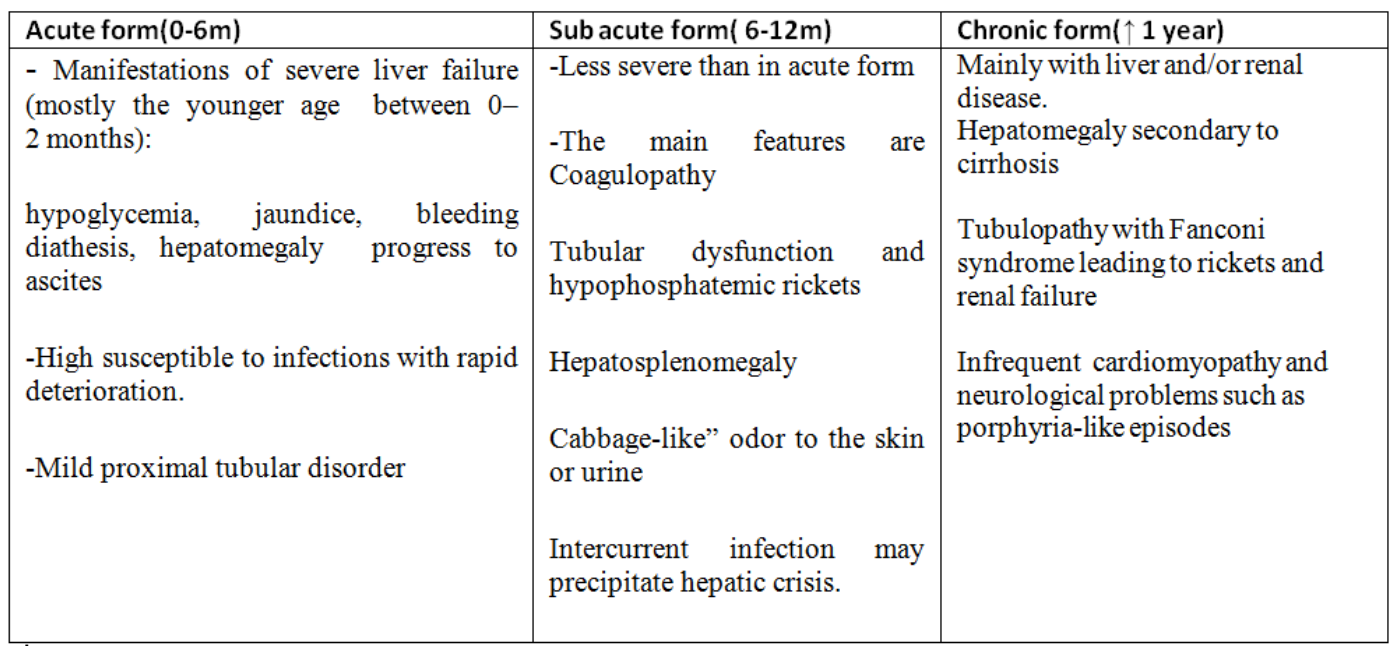

Table 2: Organs manifestation in Tyrosinemia type I.

\begin{tabular}{|c|c|c|c|}
\hline Liver manifestation & Kidney manifestation & $\begin{array}{l}\text { Neurological } \\
\text { manifestation }\end{array}$ & $\begin{array}{l}\text { Other systems } \\
\text { manifestation }\end{array}$ \\
\hline $\begin{array}{l}\text {-Liver dysfunction: } \\
\text { jaundice hypoglycemia } \\
\text { hypoproteinemia } \\
\text { eadema, ascites } \\
\text { Bleeding tendency } \\
\text { Acute liver failure } \\
\text { Liver cirrhosis } \\
\text { Hepatocellular } \\
\text { carcinoma }\end{array}$ & $\begin{array}{l}\text {-Fanconi syndrome } \\
\text { (aminoaciduria, } \\
\text { glucosuria, phosphaturia } \\
\text { and renal tubular } \\
\text { acidosis) } \\
\text {-Hypophosphatemic } \\
\text { rickets } \\
\text {-Nephrocalcinosis } \\
\text {-Osteoporosis } \\
\text {-Chronic renal failure }\end{array}$ & $\begin{array}{l}\text {-Intermittent Porphyria } \\
\text { like neurologic crises } \\
\text {-Acute progressive } \\
\text { ascending motor } \\
\text { neuropathy/respiratory } \\
\text { failure }\end{array}$ & $\begin{array}{l}\text {-skeletal muscle } \\
\text { weakness due to } \\
\text { carnitine deficiency } \\
\text { secondary to the renal } \\
\text { tubular Fanconi } \\
\text { syndrome } \\
\text {-Cardiomyopathy } \\
\text {-Growth failure }\end{array}$ \\
\hline
\end{tabular}

Table 3. HTI Diagnostic tests

\begin{tabular}{|l|l|}
\hline Initial tests & Variables Specific/less specific tests \\
\hline $\begin{array}{l}\text { Blood: Liver function tests: bilirubin } \\
\text { total and direct, AST, ALT, GGT, } \\
\text { albumin, ALP, Glucose }\end{array}$ & $\begin{array}{l}\text { Blood: Plasma Amino acid (quantitative) elevated tyrosine, } \\
\text { methionine, and phenylalanine }\end{array}$ \\
$\begin{array}{l}\text { Coagulation: PT, PTT, fibrinogen, } \\
\text { factor II, VII, IX, XI, and XII levels }\end{array}$ & $\begin{array}{l}\text { Urine: Succinylacetone concentration in the urine(the most } \\
\text { useful test) } \\
\text { Organic acids and succinylacetone(may not be sufficiently } \\
\text { sensitive) }\end{array}$ \\
$\begin{array}{l}\text { Urea, electrolytes, creatinine, Ca, } \\
\text { PO4, CBC, ammonia (in acuteliver } \\
\text { failure) }\end{array}$ & $\begin{array}{l}\delta \text {-aminolevulinic acid ( } \delta \text {-ALA) in acute neurologic Porphyria } \\
\text { like episodes }\end{array}$ \\
$\begin{array}{l}\alpha \text {-fetoprotein } \\
\text { Urine: Fanconi syndrome (glucose, } \\
\text { protein, PO4, renal tubular acidosis). } \\
\text { TRP, } \beta 2 \text {-microglobulin } \\
\text { Calcium/creatinine ratio }\end{array}$ & $\begin{array}{l}\text { Others: } \\
\text { Imaging: ultrasound examination of the liver and kidneys } \\
\text { Multi detector CT scan or MRI (if nodules are present in the } \\
\text { liver), Colour-doppler to assess the hepatic vessels and portal } \\
\text { hypertension. }\end{array}$ \\
& $\begin{array}{l}\text { Bone X-ray in case of rickets } \\
\text { Molecular genetic testing }\end{array}$ \\
\end{tabular}

AST aspartate aminotransferase, ALT alanine aminotransferase, GGT $\gamma$ glutamyl transpeptidase, ALP alkaline phosphatase, PT Prothrombin time, PTT partial thromboplastin time, Ca Calcium, PO4 phosphate, CBC Complite blood count, AFP $\alpha$-fetoprotein, TRP Tubular re-absorption of phosphate, DBS dried blood spots

Table 4. Management and treatment in HTI. 


\begin{tabular}{|l|l|}
\hline Medication andProcedures & Diet \\
\hline $\begin{array}{l}1 . \text { Nitisinone (NTBC) orally } \\
\text { Dose of } 1 \mathrm{mg} / \mathrm{kg} / \text { day (as standard dose). } \\
2 \mathrm{mg} / \mathrm{kg} / \text { day (in acute liver failure) } 1-3 \text { a day. }\end{array}$ & $\begin{array}{l}\text { 1. A special milk formula (tyrosine and } \\
\text { phenylalanine free) e.g., Tyros } 1^{\circledast}, \text { Tyrex }-1^{\ominus} \\
\text { try } 1 \text { or } 2 \text { or Anamix TYR. }\end{array}$ \\
$\begin{array}{l}\text { 2.Treatment for acute liver failure: supportive } \\
\text { measures including clotting factors, albumin, } \\
\text { electrolytes correction, plasma, correction of } \\
\text { acid-base status and hyperammonia, treatment of } \\
\text { infections, Vitamin K, respiratory support and } \\
\text { appropriate fluid management }\end{array}$ & $\begin{array}{l}\text { 2. Food pattern: Protein-restricted diet (a } \\
\text { maintains plasma tyrosine levels below } 500 \\
\mu \text { mol/L and plasma phenylalanine levels in } \\
\text { the normal range }(30-80 \mu \text { mol/1). }\end{array}$ \\
$\begin{array}{l}\text { 3. Treatment of hypophosphatemic rickets with } \\
\text { phosphate orally and Vitamin D. }\end{array}$ & \\
$\begin{array}{l}\text { 4. Vitamins and micronutrients. } \\
\text { 5. Carnitine deficiency with L-Carnitine }\end{array}$ & \\
$\begin{array}{l}\text { 6. Liver transplantation should be considered in } \\
\text { acutely ill infants fails to respond to Nitisinone. }\end{array}$ & \\
\hline
\end{tabular}

Table 5: Nitisinone (NTBC) side effects.

\begin{tabular}{|c|c|c|}
\hline $\operatorname{common}(<1 / 10-\geq 1 / 100)$ & Uncommon $(<1 / 100-\geq 1 / 1000)$ & Rare \\
\hline $\begin{array}{l}\text { Thrombocytopenia leucopenia } \\
\text { granulocytopenia } \\
\text { Conjunctivitis, photophobia, } \\
\text { corneal opacity, keratitis, eye pain }\end{array}$ & $\begin{array}{l}\text { Blepharitis } \\
\text { Pruritus, exfoliative dermatitis, } \\
\text { erythematous rash. } \\
\text { Leucocytosis }\end{array}$ & $\begin{array}{l}\text { Bloated abdomen, dark } \\
\text { urine, abdominal pain, } \\
\text { feeling of tiredness or } \\
\text { weakness, headache, light- } \\
\text { colored stools, loss of } \\
\text { appetite, weight loss, } \\
\text { vomiting, and jaundice. }\end{array}$ \\
\hline
\end{tabular}

Table 6. Disease Monitoring in HTI

\begin{tabular}{|c|c|c|c|c|c|c|}
\hline \multirow[t]{2}{*}{ Type of evaluation } & \multirow[t]{2}{*}{ Baseline } & \multicolumn{2}{|c|}{$\begin{array}{l}\text { First } 6 \text { months of } \\
\text { treatment }\end{array}$} & \multicolumn{3}{|c|}{ After 6 months with treatment } \\
\hline & & Monthly & $\begin{array}{l}\text { Every } \\
3 \mathrm{mo}\end{array}$ & $\begin{array}{l}\text { Every } \\
3 \mathrm{mo}\end{array}$ & $\begin{array}{l}\text { Every } \\
6 \mathrm{mo}\end{array}$ & Yearly \\
\hline $\mathrm{CBC}$ & $\sqrt{ }$ & $\mathrm{v}$ & & & $\mathrm{V}$ & or $\mathrm{V}$ \\
\hline Serum alpha feto protein AFP & $\mathrm{v}$ & $\mathrm{v}$ & & $\mathrm{v}$ & or $\mathrm{V}$ & \\
\hline $\begin{array}{l}\text { Plasma methionine, phenylalanine } \\
\text { and Tyrosine }\end{array}$ & $\sqrt{ }$ & $\mathrm{V}$ & & $\mathrm{v}$ & & \\
\hline PT & $\mathrm{V}$ & Until N & & & & \\
\hline PTT, fibrinogen & $\mathrm{V}$ & Until $\mathrm{N}$ & & $\bullet$ & & \\
\hline Bilirubin & V & & & & & $\bullet$ \\
\hline AST,ALT,ALP,GGT, albumin & $\sqrt{ }$ & Until $\mathrm{N}$ & & & & $\bullet$ \\
\hline $\begin{array}{l}\text { Urea/electrolytes, calcium, phosphate } \\
\text { Creatinine, TRP }\end{array}$ & $\mathrm{v}$ & V & & & & $\mathrm{v}$ \\
\hline Urine Fanconi, Succinylacetone & $\mathrm{v}$ & $\sqrt{ }$ & & & & $\sqrt{2} \mathbf{z}$ \\
\hline $\begin{array}{l}\text { Imaging: Renal ultrasound, Skeletal } \\
\text { X ray }\end{array}$ & $\mathrm{v}$ & & & & & $\bullet$ \\
\hline Abdominal CT or MRI & $\mathrm{v}$ & & & & & $\mathrm{v}$ \\
\hline Blood Nitisinone concentration & & $\mathrm{v}$ & & $\mathrm{v}$ & & \\
\hline $\begin{array}{l}\text { Iron and ferritin, vitamins } \mathrm{A}, \mathrm{D}, \mathrm{E}, \\
\text { Folate \& vitamin } \mathrm{B}_{12}, \text { Micronutrients } \\
(\mathrm{Se}, \mathrm{Zn}, \mathrm{Cu})\end{array}$ & & & & & $\sqrt{ }$ & \\
\hline $\begin{array}{l}\text { Growth and nutrient intake (Weight, } \\
\text { Height) }\end{array}$ & $\mathrm{v}$ & $\sqrt{ }$ & $\sqrt{ }$ & $\sqrt{v}$ & & \\
\hline $\begin{array}{l}\text { Developmental * by DAS ( } \\
\text { intellectual development). }\end{array}$ & & & & & & \\
\hline
\end{tabular}

- If indicated clinically is if poor response, * be before school entry, PT Prothrombine time, PTT Partial thromboplastin time, N Normal, AST, ALT aspartate and alanine aminotransferase, ALP alkaline phosphatase, GGT $\gamma$ glutamyl transpeptidase, TRP Tubular re-absorption of phosphate, DAS Differential Ability Scale 
A Review of Metabolic Disorder of Amino Acid Tyrosinemia type I: When to Suspect and how to ..

Table 7: Differential diagnosis of HTI on base of clinical presentation, showing differential diagnosis of those diseases with similar presentation [22, 43, 44].

\begin{tabular}{|c|c|c|c|c|}
\hline Liver disease & Renal disease & Neurological disease & Rickets & $\begin{array}{l}\text { Laboratory } \\
\text { results(blood) }\end{array}$ \\
\hline $\begin{array}{l}\text {-Galactosemia } \\
\text {-Hereditary fructose } \\
\text { intolerance or Fructose } \\
\text { 1,6diphosphatase } \\
\text { deficiency, } \\
\text {-Niemann-PickC } \\
\text { disease } \\
\text {-Wilson disease } \\
\text {-Neonatal } \\
\text { hemochromatosis } \\
\text {-Hemophagocytic } \\
\text { lymphohistiocytosis } \\
\text {-Mitochondrial } \\
\text { cytopathies, CDG } \\
\text {-Transaldolase } \\
\text { deficiency } \\
\text {-Drugs and toxicity, } \\
\text { Infection } \\
\text {-Herbal medicines }\end{array}$ & $\begin{array}{l}\text { Cystinosis } \\
\text { Lowe syndrome } \\
\text { Fanconi syndrome } \\
\text { Renal-tubular } \\
\text { acidosis }\end{array}$ & $\begin{array}{l}\text { Acute-intermittent } \\
\text { porphyria } \\
\text { Cerebral hemorrhage } \\
\text { Meningitis } \\
\begin{array}{l}\text { Hypernatremic } \\
\text { dehydration }\end{array}\end{array}$ & $\begin{array}{l}\text { VitaminD deficiency } \\
\text { nutritional/genetic } \\
\text { Fanconi syndrome } \\
\text { Hypophosphatasia } \\
\text { Hypophosphatemic } \\
\text { rickets } \\
\text { VitaminD-dependent } \\
\text { rickets }\end{array}$ & $\begin{array}{l}\uparrow \text { Tyrosine } \\
\text { Immature liver } \\
\text { High-protein diet } \\
\text { Tyrosinemia type II } \\
\text { or III } \\
\text { Other liver disease } \\
\uparrow \text { methionine } \\
\text { Homocystinuria } \\
\text { Other Disorders of } \\
\text { methionine } \\
\text { metabolism }\end{array}$ \\
\hline
\end{tabular}

CDG Congenital disorders of glycosylation

Table 8: Pathogenic HTI genetic mutation in different population [22, 47].

\begin{tabular}{|l|l|}
\hline population & population-specific pathogenic variants \\
\hline Ashkenazi Jewish & p.Pro261Leu (P261L) \\
\hline Finnish & p.Trp262Ter (W262X) \\
\hline French Canadian & c.1062+5G $>$ A (IVS 12+5 G $>$ A) \\
\hline Northern European & c.1062+5G $>$ A (IVS 12+5 G $>$ A) \\
\hline Pakistani & p.Gln64His (Q64H) \\
\hline Scandinavian & p.Gly337Ser (G337S) \\
\hline Southern European & c.554-1G $>$ T (IVS 6-1 G $>$ T) \\
\hline Turkish & p.Asp233Val (D233V) \\
\hline
\end{tabular}

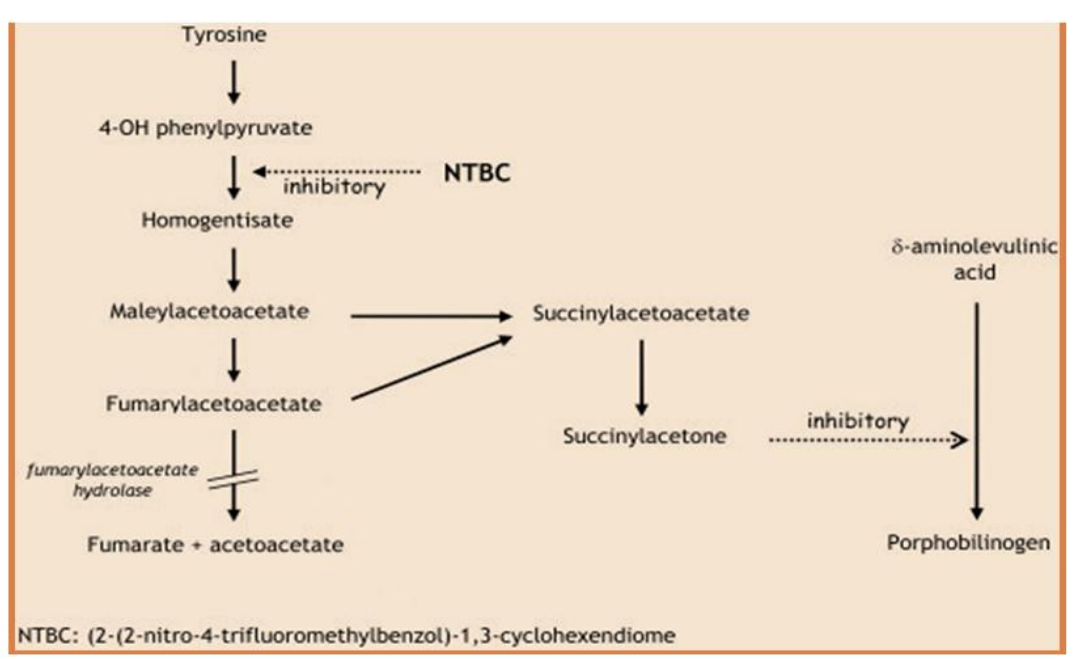

Fig.1 Tyrosine pathway: in fumarylacetoacetic acid hydrolase (FAH) enzyme deficiency, fumarylacetoacetic acid is converted to succinylacetoacetate and then to succinylacetone showing the action of medication Nitisinone (NTBC, Orfadin). 